\title{
ダイヤモンドアンビル法を主体と するキューバ鉱相変化の観察
}

\author{
Phase change of cubanite studied \\ with diamond anvil cell

$\begin{array}{lc}\text { 池田 } & \text { 正清 (Masakiyo Ikeda)* } \\ \text { 石井 努 (Tsutomu Ishii)* } \\ \text { 宮本 } \\ \text { 久欽生 (Yoshinari Miyamoto)* } \\ \text { 久米 } \text { 昭一 (Shoichi Kume)* }\end{array}$

\begin{abstract}
A diamond anvil cell was used to investigate the phase relations between low and high temperature phases of cubanite and also between high pressure polymorph and the above-stated phases. Initial slope of low-high temperature phase boundary is about $200^{\circ} \mathrm{C} / \mathrm{GPa}$, showing a good coincidence with the reported value. Compressions of both low and high temperature phases produce a high pressure modification isostructural with troilite. The conversion accompanies an increase in density of $23 \%$. This compaction is induced by a change of coordination numbers of anions surrounding cations from 4 to 6 . The dense phase reverts to high temperature phase but not to low temperature. No significant difference was seen in heat capacities of low and high temperature phases. This implies the structural resemblance between two phases. The change of enthalpy accompanied with the transformation between low and high temperature phases was mainly attributed to the order-disorder transitions of both magnetic and ionic configurations in the lattice.
\end{abstract}

\section{1. はじめに}

かつて登山家の目標が未登頂の山の征服にあったように，鉱物合成を志向する者はこれま で合成に成功していない鉱物に対して，最大の関心を抱く。斜方晶キューバ鉱 $\left(\mathrm{CuFe}_{2} \mathrm{~S}_{3}\right)$ はこの対象の中心に大きく位置づけられるが，これまで目的達成に払われた努力は主に熱処 理あるいは水熱条件下での実験に向けられて来た（苗木，1972）。

われわれはこれに圧力といら別の要素を導入した実験を試みた結果，斜方晶相の作製は果 せなかったが、トロイライトおよび NiAs 型高圧相の存在を確認した (Miyamoto et al, 1980 ; 宮本ら，1980)。この実験の途上，低温相である斜方晶相が高温で安定な立方晶ある いは高圧相に転移する温度・圧力条件もあるていど明らかになった。これらの実験では高温 ・高圧処理後, 急冷して試料をとり出してから生成相の同定を和こなら方法をとったが, 変

* 大阪大学教養部 
ダイヤモンドアンビルを主体とするキューバ鉱相変化の観察

化の様相をさらに詳しく正確に調查するため, 加熱加圧を同時に進めながら, 構造変化をそ の場観察できるダイヤモンドアンビルセルを試作した。ここではえられた結果の一部ならび に物性測定の結果を紹介する。

\section{2. 実験}

i) 試料低温相の試料として河守鉱山産のものを使用した。合成用出発原料としては 純度 $99 \%$ 以上の高純度の銅・鉄金属粉拈よびイオウ粉を $1: 2: 3.3$ のモル比に混合し，十分 攪拌した。イオウは逃散性を考慮し，過剩に加えられた。混合粉末は圧縮してペレット状と し, シリカチュープに真空封入して $400^{\circ} \mathrm{C} \cdot 1$ 日仮燒後, $750^{\circ} \mathrm{C}$ 昇温して 2 日間反応後, 急 冷した。高圧相は天然産低温相抽よび合成高温相を六面体加圧装置 (Osugi et al, 1964) に よって処理して得られた。生成物は顕微鏡で均一相であることを確認し, X 線粉末回折で目 的物であることを同定した。

ii）ダイヤモンドアンビルセルアンビル加圧部は塩田ら $(1981,1982)$ によてすで 飞発表されたものを使用した。加圧先端部には $0.8 \mathrm{~mm} \phi$ のダイヤを用いた。ガスケット材 には0.1〜0.25mm 厚さのステンレスまたは U-700 合金を用い，中心部を $0.2 \sim 0.5 \mathrm{~mm} \phi$ に穿孔した。

受光スリットは従来内径 $1.12 \mathrm{~mm}$ のステンレス製パイプが使用されてきた。このスリッ トでは回折 X 線のごく限られた部分しか利用出来ず $\mathrm{S} / \mathrm{N}$ の高い回折パターンを得るために は，一晚以上露光しなければならなかった。 $5 \mathrm{GPa}$ 以上の圧力発生にはガスケット径を 0.2 mm以下にしなければならず, そのために試料量も少なくなり， S/N 比はさらに悪くなる。 露光時間延長にも限界があるため, 今回新たに第 1 図に示されるよらな受光スリットを考案 した。このスリットは回折 X 線を線状に切りとる形になっており,これで11. $3 \mathrm{~mm} \phi$ の X線 検出空を有効に利用出来るようになった。この改良により同一条件でのカウント数は約 20 倍 に向上した。スリットの切り口は敩密にはだ円のわん曲であるが，計算によりだ円の曲率円 のそれで近似し得た。ガスケットには絶縁耐熱性接着剂を塗布してからニクロム簿を貼付 け，これに通電することによって試料を加熱した。測温は C-A 熱電対をアンビル先端に取 付けておこなった。

その概略を第 2 図に示す。圧媒体にはメタノール/エタノール $1 / 4$ 混合液を用いた。発 生圧力の検定はルビーの螢光 $\mathrm{R}_{1}$ 線の加圧シフト (Barnett et al., 1973) を用いて抗こな った。加熱による $\mathrm{R}_{1}$ 線のシフトは加圧と独立として取扱った (Wunder et al., 1981)。

$\mathrm{X}$ 線回折には Ge 固体検出器によるエネルギー分散方式を採用した。加熱実験の場合には

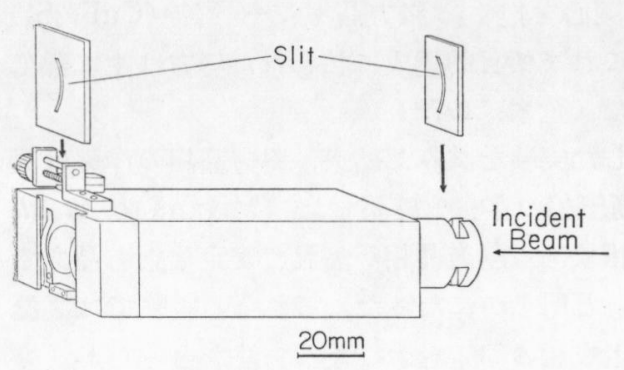

第1図 受光スリット

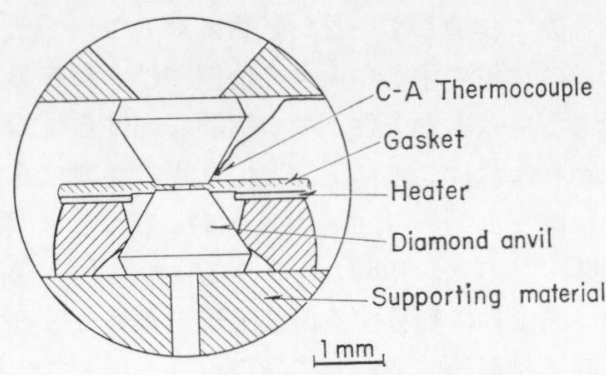

第 2 図 高压発生部と加熱用ヒーター (ダイヤモンドアンビルセル) 
温度平衡に達した後（約20分後），測定を開始した。

iii）示差走査熱量計 (DSC) DSC を使った熱容量測定は, 少量の試料でも精度よく行 える(O’Nei11，1966）ので，本実験に適した装置であった。

iv）磁気測定帯磁率の測定は高温相について, Faraday 法によりおこなった。標準 物質としては Mohr 塩を使用した。

\section{3. 結果および考察}

第 3 図は種々の温度・圧力条件で得られた実験結果をまとめたものである。5GPa 付近で

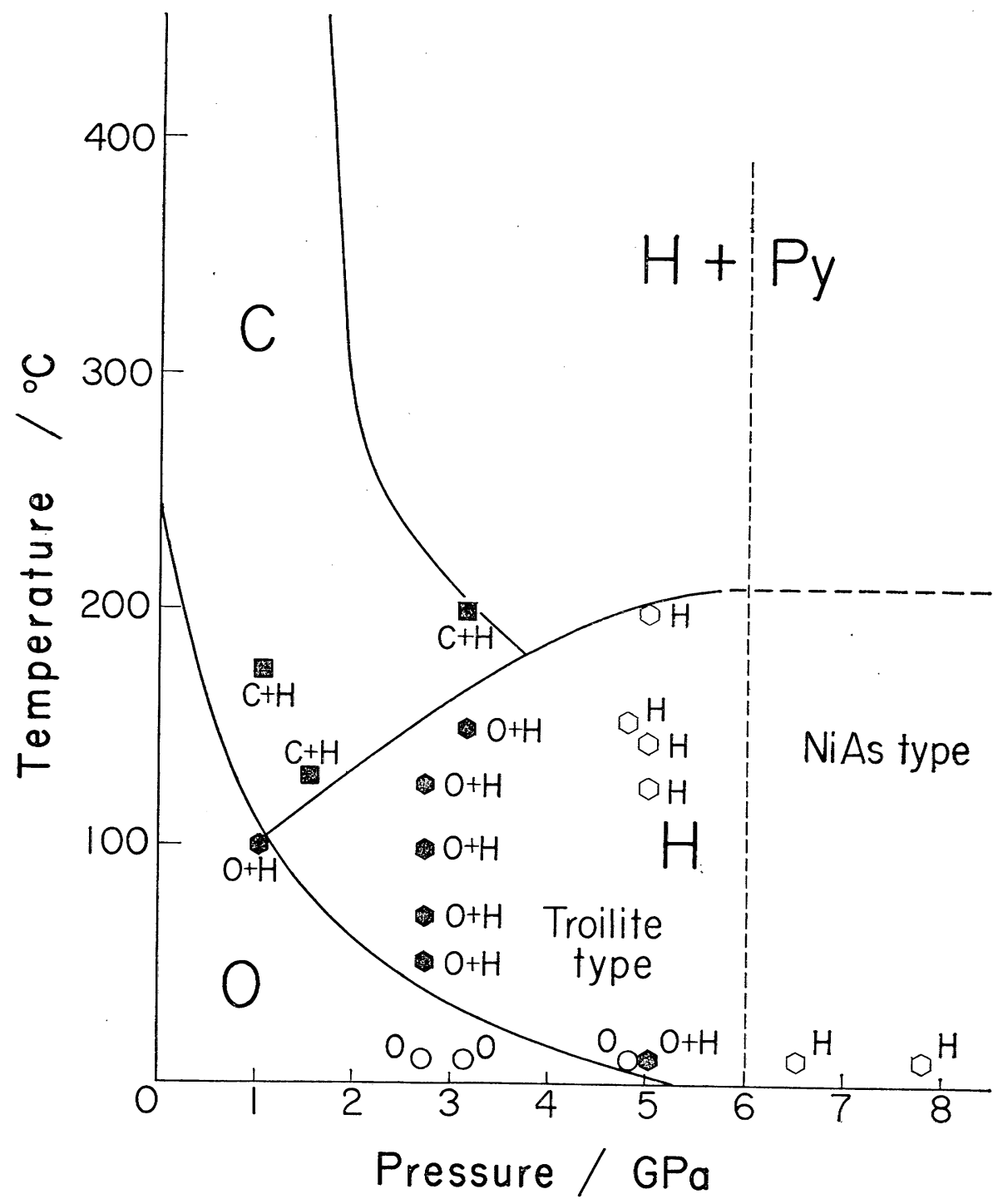

第 3 図 高圧加熱下での生成状態図

$0:$ 低温相

$\mathrm{C}:$ 高温相

$\mathrm{H}$ : トロイライト型相

$\mathrm{H}+\mathrm{Py}$ ：トロイライト型相一オウテッ鉱型相共存(Miyamoto et al. 1980) 
加熱を行なうと, 低温相からトロイライト型高圧相の回折像へと変化し, 加圧加熱下での高 圧相転移がより直接的に確認できた。

実験的に求めた図 3 の P-T 生成図は限られた時間内で求めたものであり, 必ずしも熱 平衡状態にあるとは言い難いが，低温相領域は室温付近で大きく高圧側に広がっていること が認められる。

低温相一高温相間の相境界線の初期勾配を求めると $-200^{\circ} \mathrm{C} / \mathrm{GPa}$ となる。苣木 (1972) は転移温度の圧力変化を $-100 \sim 400^{\circ} \mathrm{C} / \mathrm{GPa}$ と報告して抢り，本実験の結果と一致する。 また室温より $200^{\circ} \mathrm{C}$ ま゙の比較的低温部において低温相一トロイライト型相間および高温相 一トロイライト型相間境界は下方に凸状の曲線で示される。これは前回 (Miyamoto et al., 1980) の報告よりも精密化された結論であり, その場観察により始めて明確にされる結果と して注目される。

第 4 図に $4.8 \mathrm{GPa}$ 室温及び $153^{\circ} \mathrm{C}$ での回折像を示す。(114) と（121）の回折線は一部 重なり合っているものとみなされる。6GPa 以上の高圧領域で NiAs 型構造に相転移し 得 るかどうかを確かめるため，室温で $7.8 \mathrm{GPa}$ まで圧を上げ X 線回折を行なった。(102) 回

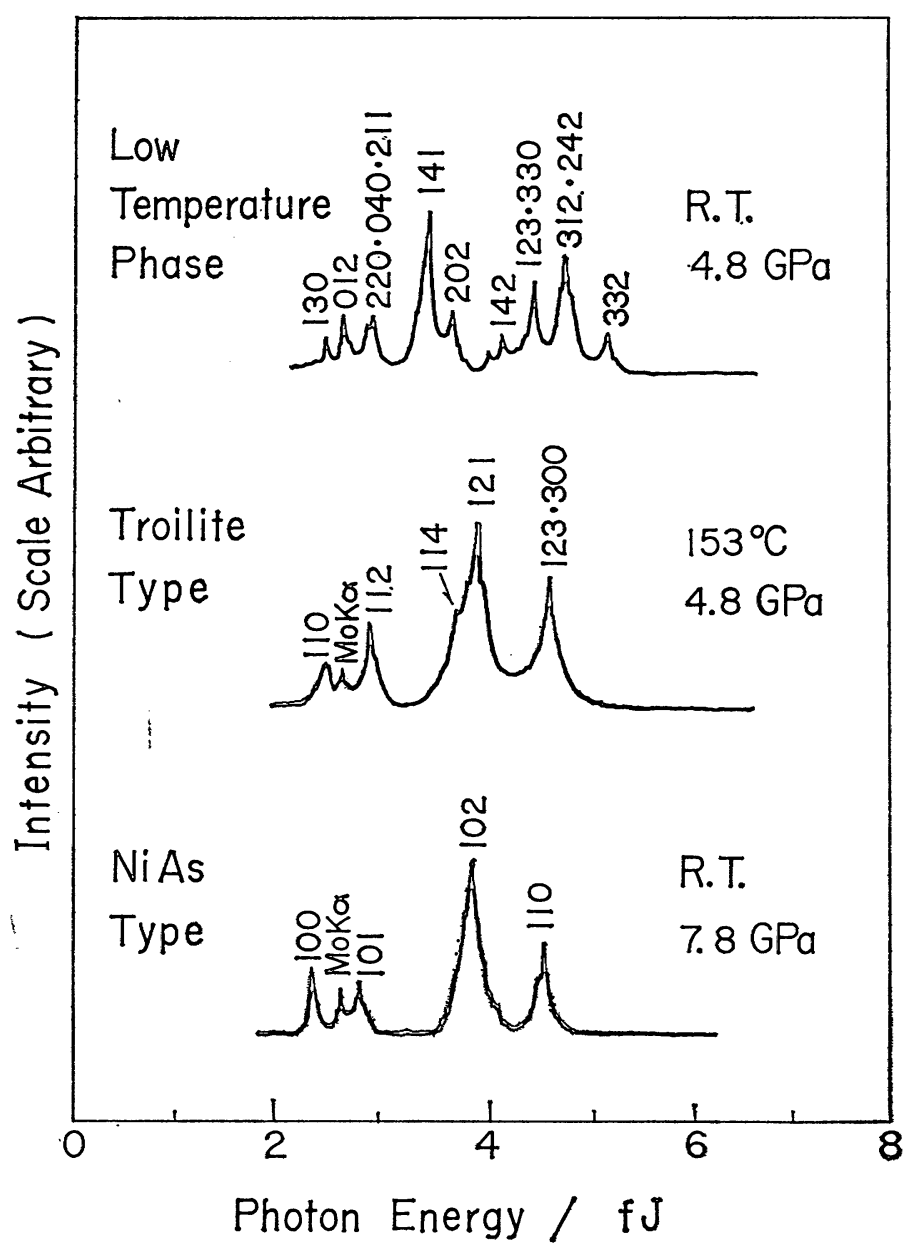

第 4 図 高圧下での低温相およびトロイライト型・NiAs 型高圧相回折パターン 
折ピークの形は対称的であり，シングルピークとみなされる。またトロイライト型の特徵ピ 一クである (121) に相当するピークはみられず各ピークは NiAs 型として指数づけが可能 であった。トロイライト, NiAs 型の理想構造では陽イオンサイトは同等であることから， 銅・鉄イオンの秩序配列は考元にくい。

トロイライト型高圧相は単位格子中に 12 個の $\mathrm{Cu}_{1 / 3} \mathrm{Fe}_{2 / 3} \mathrm{~S}$ なる分子が存在すると考えられ る。これからトロイライト型高圧相の密度は $4.98 \mathrm{Mg} / \mathrm{m}^{3}$ と計算される。低温相・高温相と 比べ，23\%程度密度が増加する。この密度増加は大きいが，これは陽イオンがすべて四配位 から六配位に変化したことに起因すると考兄られる。実際この高圧相の密度は, トロイライ トのそれ $\left(4.84 \mathrm{Mg} / \mathrm{m}^{3}\right)$ と大差なく，従って構造的にも無理がないと言える。

このような高圧相転移は Fe-S 系鉱物にも予想される。Takeno ら (1970) は湿式合成法 により $50^{\circ} \mathrm{C} ・ 1$ 気圧に执いてセンアェン鉱構造を持つ $\mathrm{FeS}$ の準安定相 $(\mathrm{a}=5.42 \AA$, 計算 密度 $3.68 \mathrm{Mg} / \mathrm{m}^{3}$ ) の存在を確認した。この物質を加圧すると, より高い配位数を持つ $1 \mathrm{C}$ ジリェウテツ鉱（計算密度 $4.8 \mathrm{Mg} / \mathrm{m}^{3}$ ) 飞転移すると期待される。ジリュウテッ鉱は $\mathrm{NiAs}$ 型構造であるので，予想される転移に類似したものとなり，転移に際してキューバ鉱の場合 以上の密度増加（３0\%）を示すはずである。

$200^{\circ} \mathrm{C}$ 以上の高圧分解領域で生成した六方晶（トロイライト型）の格子定数はトロイライ 卜型高圧相のそれょり若干大きい值となる。この理由はオウテッ鉱の析出に伴なって $\mathrm{Fe}, \mathrm{S}$ イオンがぬけたために格子が多少らくらんだことによると考えられる。

第 5 図は今回得られた高温相・低温相の熱容量曲線を示す。図から見られるとおり，高温 相・低温相の間には実験的に検出できるほどの熱容量の差は認められない。両相とも陽イオ ンはS の四面体サイトに入り，陰陽両イオン間の最近接距離も近い值をとるという構造上の 類似を考慮すれば, 格子熱容量の差のないことは容易に理解される。低温相の高温相への転 移は, $513 \mathrm{~K}$ から起こり始め $550 \mathrm{~K}$ 付近むで続く緩慢なものである。転移に伴ならェンタル ピー变化は $16 \mathrm{~kJ} / \mathrm{mole}$ 前後である。この值は溝田（1978）による報告值よりやや大きい。

第 6 図に高温相キューバ鉱の逆帯磁率の温度変化をしめす。測定温度範囲では常磁性であ り，直線的に変化している高温側の勾配より求めた有効ボーア磁子数は 7.6 となった。また 漸近キュリー温度が負をしめすことから，チッ素温度以下で反強磁性的配列をしめすものと

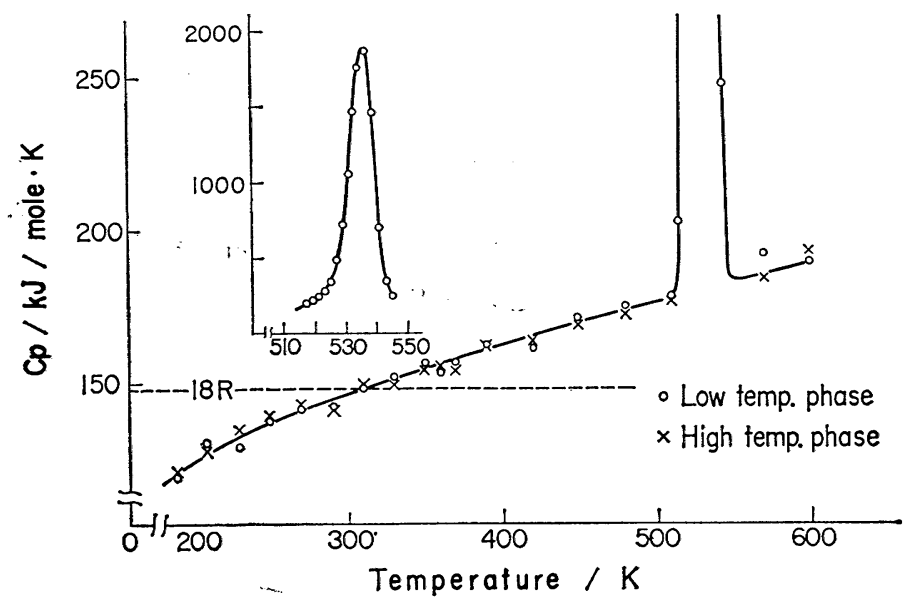

第 5 図 高温相および低温相の熱容量曲線 


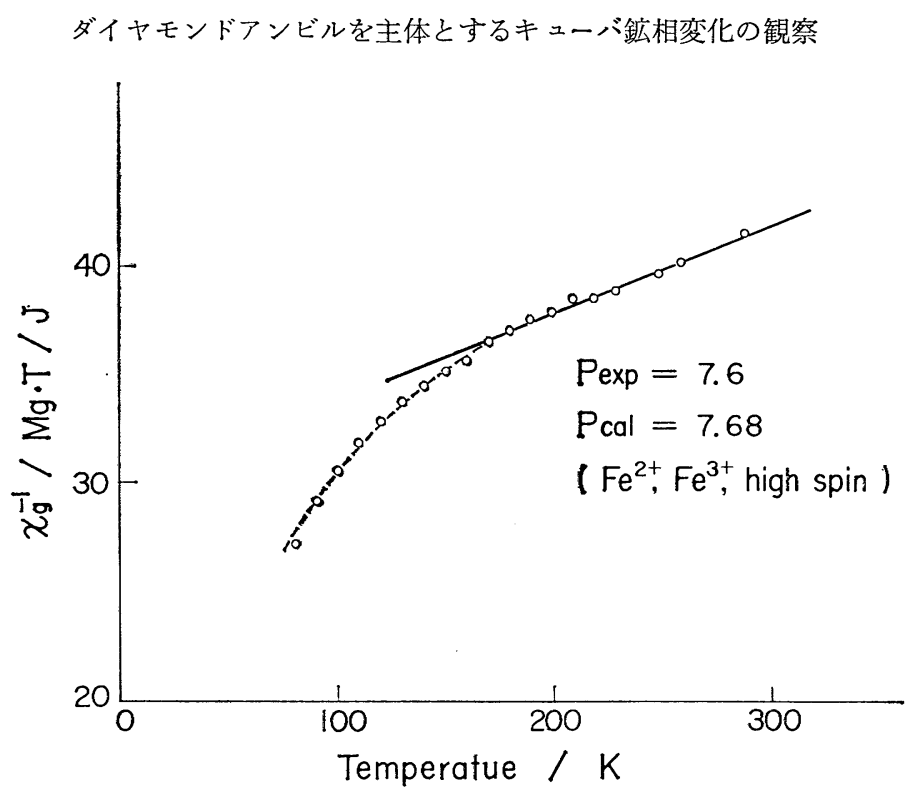

第6 図 高温相の逆帯磁率の温度変化

思われる。

一般に相境界ではエンタルピー変化，エントロピー変化をそれぞれ， $\Delta \mathrm{H} ， \Delta \mathrm{S}$ とすれば

$$
\Delta \mathrm{H}=\mathrm{T} \cdot \Delta \mathrm{S}-1
$$

が成立する。 $\Delta \mathrm{S}$ は格子・配置・磁気エントロピー等の寄与の和であらわすことができ，そ れに対応して(1)より各々の項のエンタルピー変化が見つもれる。低温相から高温相への転移 に伴い, イオウの充てんが六方最密から立方最密と変化するのと同時に, $\mathrm{Fe} ・ \mathrm{Cu}$ イオンの 配列が秩序状態から無秩序状態へと変化する。

さらに磁気的性質にも変化がみられる。まず金属イオンの秩序一無秩序配列にともならエ ントロピー変化・エンタルピー変化は, 低温相では $1 \mathrm{~mole}$ 当り $2 \mathrm{~N}$ 個の $\mathrm{Fe}$ イオン位置と $\mathrm{N}$ 個の $\mathrm{Cu}$ イオン位置に各イオンが分配され，高温相になると $3 \mathrm{~N}$ 個の位置に無秩序分布す ると考觉ると，それぞれの上限の変化量は次のようにあらわされる。

$$
\begin{aligned}
& \Delta \mathrm{Sconf}=\mathrm{k} \cdot \ln \frac{3 \mathrm{~N} !}{2 \mathrm{~N} ! \cdot \mathrm{N} !}=\mathrm{R}(3 \ln 3-2 \ln 2) \\
& \Delta \mathrm{Hconf}=\mathrm{To} \cdot \Delta \mathrm{S} \operatorname{conf}=8.2 \mathrm{~kJ} / \mathrm{mole}
\end{aligned}
$$

なお, 転移温度 To は転移の初期温度 $513 \mathrm{~K}$ を選んだ。ついで, 磁気的変化による寄与に ついて考えてみる。低温相については，Fe イオンは 2 価・3 価で高スピン状態にあり, $200^{\circ} \mathrm{C}$ 付近まで, 磁気モーメントは反強磁性的配列から少し傾いた弱い強磁性状態にあり, $200^{\circ} \mathrm{C}$ 付近で帯磁率が急激に小さくなることが Sawada ら (1962) や Townsend ら(1973) によって報告されている。

高温相では, $\mathrm{Fe}^{2+}, \mathrm{Fe}^{3+}$ の高スピン状態でスピンのみの寄与と仮定して計算した有効ボー ア磁子数

$$
\mathrm{P}=\left(5.92^{2}+4.90^{2}\right)^{1 / 2}=7.68
$$

と実験值 7.6 がよく一致することから, Feイオンは低温相と同じ 2 価・ 3 価の高スピン状態 であるとみなされる。またこの相は磁気転移点が $77 \mathrm{~K}$ 以下になっていると考えられること から，室温ではすでに完全な常磁性状態にあると思われる。低温相から高温相への結晶相転 
移時に生ずる帯磁率の急激な減少 (Townsend et al., 1973) あやはり, 金属イオンの配置 の無秩序化にともなっておこると考えられることから，一次的な磁気相転移とみなされる。 単純なモデルであるが，結晶相転移点以下では磁気スピンは完全秩序状態にあり，転移点以 上では完全に無秩序状態になると仮定した場合の磁気エントロピー変化・エンタルピー変化 は次式であらわされる。

$$
\begin{aligned}
& \Delta \mathrm{Smag}=2 \mathrm{R} \ln \left(2 \cdot \frac{3.2}{2}+1\right)=2.87 \mathrm{R} \\
& \Delta \mathrm{Hmag}=\mathrm{To} \cdot \Delta \mathrm{Smag}=12.3 \mathrm{~kJ} / \mathrm{mole}
\end{aligned}
$$

ここでスピンの值 $\mathrm{S}=3.2 / 2$ は低温相の中性子回折より得られた $\mathrm{Fe}$ イオンの平均磁気モーメ ント 3. $2 \mu_{\mathrm{B}}$ (Wintenberger et al., 1974) から求めた。これらの值は磁気エントロピー・ エンタルピー変化の上限を与えるもので, 実際には Townsend ら（1973）の報告にみられ るように室温以上で低温相の帯磁率にわずかの増加傾向がみられることから, 転移温度 To 以下ですでにある程度の磁気モーメントのゆらぎが生じているとみなされ，その寄与を考慮 すると $\Delta \mathrm{Smag}, \Delta \mathrm{Hmag}$ は各々以下のように減少すると思われる。

$$
\begin{aligned}
& \Delta \mathrm{Smag}=2.87 \mathrm{R}-\delta \\
& \Delta \mathrm{Hmag}=12.3-\Delta
\end{aligned}
$$

ここで $\delta, \Delta$ は磁気モーメントのゆらぎによる寄与で現時点での定量は困難である。格子変 化のエントロピー・エンタルピーへの寄与については先に述べたように低温相・高温相間に エネルギー的に大差はないと考光られるのでこの寄与は小さいと考光られる。従ってこれら の寄与によるエンタルピー変化は

$$
\begin{aligned}
\Delta \mathrm{H} & =\Delta \mathrm{H} \text { conf }+\Delta \mathrm{Hmag}+\Delta \text { Hlattice } \\
& \simeq 8.2+12.3-\Delta \leq 20.5 \mathrm{~kJ} / \text { mole }
\end{aligned}
$$

と見つもることができる。 $\Delta \mathrm{H}$ の測定值, $16.4 \mathrm{~kJ} / \mathrm{mole}$ はこの条件を満足していることから， この転移の潜熱の大部分は磁気的及び金属イオンの配置の無秩序化によっていると考元られ る。

次に熱容量のふるまいについて考えてみる。両相とも高温での格子熱容量は $18 \mathrm{R}(3 \mathrm{R} \times 6$ 原子， $151 \mathrm{~kJ} / \mathrm{mole} ・ \mathrm{~K})$ ていどと見つもられるが，低温相・高温相とも，これより高い値を しめしている。低温相では先に述べたように弱い強磁性状態にあって, 転移温度以下で少し 磁気モーメントのゆらぎが生じて扣り，それの熱容量への寄与が考㝋られるが，高温相では すでに常磁性状態であるため同様の寄与は考它にくい。

差の一部は定積熱容量から定圧熱容量への補正項 $\mathrm{TV} \beta^{2} / \kappa(\mathrm{T}:$ 温度 $; \mathrm{V}:$ モル体積； $\beta$ : 熱膨脹率： $\kappa:$ 圧縮率， $\sim 5.5 \mathrm{~kJ} / \mathrm{mole} \cdot \mathrm{K}$ ) で説明されるが，残りが何に起因するかは不明で ある。

高圧相経由による低温相合成は残念ながら成功しなかった。低温相一高温相転移のエンタ ルピー変化の大部分は陽イオン分布の無秩序化とそれによる磁気転移に伴ならものとみなさ れる。このことは陽イオン分布の無秩序化が転移点直下で生ずるとする Putn1s (1977) の 電子顕微鏡観察とも矛盾しない。彼によれば立方晶構造での陽イオン分布の秩序化は幾何学 的に生じ得ず， $\mathrm{CuFeS}_{2}$ と $\mathrm{CuFe}_{3} \mathrm{~S}_{4}$ に分解してしまう傾向が強い。高圧相の陽イオン分布 も秩序化しているとは考えにくく，従って高圧相を常圧相に戻した場合，格子ェネルギ一的 に安定な S の立方最密充填構造である高温相に戻ってしまうのであろう。 


\section{ダイヤモンドアンビルを主体とするキューバ鈗相変化の観察}

文献

Barnett, J. D., Block, S. and Piermarini, G. J. (1973): An optical fluorescence system for quantitative pressure measurement in the diamond-anvil cell, Rev. Sci. Instr., 44, 1-9.

Miyamoto, Y., Ishii, T., Kume, S. and Koizumi, M. (1980): A new polymorph of cubanite, $\mathrm{CuFe}_{2} \mathrm{~S}_{3}$. Mat. Res. Bull., 15, 907-910.

宮本欽生, 石井努, 田窪宏, 久米昭一, 小泉光恵 (1980); キューバ鉱に予想される高圧相転移, 鉱 物学雑誌, 14 特別号 2 号, 410-416.

溝田忠人 (1978)：DSC によるキューバ鉱の相転移熱および比熱の測定, 日本鉣物学会講演要旨集, 61.

O'Neill, M. J. (1966): Measurement of specific heat functions by differential scanning calorimetry. Anal. Chem., 38, 1331-1336.

Osugi, J., Shimizu, K., Inoue, K. and Yasunami, K. (1964): A compact cubic anvil high pressure apparatus. Rev. Phys. Chem. Japan, 34, 1-6.

Putnis, A. (1077): Electron microscope study of phase transformations in cubanite, Phys. Chem. Minerals, 1, 335-349.

Sawada, M., Ozima, M. and Fujiki, J. Geomag. Geoelectr., 14, 107-112.

塩田浩平, 宮本欽生・小泉光恵・久米昭一 (1981) : $\mathrm{Mg}_{2} \mathrm{GeO}_{4}$ の相变化とその圧力依存性, 日化誌, $19811542-1547$.

塩田浩平, 宮本欽生, 田窪宏, 久米昭一, 小泉光恵 (1982): $\mathrm{Ge}$ カンラン石 $\mathrm{Mg}_{2} \mathrm{GeO}_{4}$ のスピネル相 転移，岩鉱誌，特別号 3 号, 189-194.

亘木浅彦 (1972) : キューバ鉱の転移に関する熱的研究, 山口大学工学部研究報告, 22, 263-272.

Takeno, S., Zoka, H. and Niihara, T. (1970): Metastable cubic iron sulfide-with special reference to mackinawite, Am. Mineral. 55, 1639-1649.

Townsend, M. G., Horwood, J. L. and Goselin, J. R. (1973): On the weak ferromagnetism of orthorhombic $\mathrm{CuFe}_{2} \mathrm{~S}_{3}$, Can. J. Phys., 51, 2162-2165.

Wintenberger, M., Lambert-Andron, B. et Roudaut, E. (1974): Détermination de la structure magnétique de la cubanite par diffraction neutronique sur un monocristal, Phys. Stat. Sol. (a) $26,147-154$.

Wunder, S. L. and P. E. Schoen (1981): Pressure measurement at high temperatures in the diamond anvill cell, J. Appl. Phys. 52, 3772-3775.

（昭和57年11月17日 受理） 